\title{
Reflections From a Narrative Inquiry Researcher
}

\author{
D. Jean Clandinin
}

\begin{abstract}
In this interview, author, researcher, and professor D. Jean Clandinin reflects on her many years of experience as a narrative inquiry researcher, teacher, and teacher educator. She believes that growing up in a large, extended family with rooted engagement in the community set the stage for her later interest in narrative inquiry. She describes the many varied scholars who have had an influence on her and explains the basic tenets of narrative inquiry in both the classroom and research contexts. The challenges that face narrative inquiry researchers are described and she shares her vision of how things are changing. Finally, she tells one of her favorite narrative inquiry stories.
\end{abstract}

You are renowned around the world as a narrative inquirer. Can you talk about how you first became interested in the power of stories and how your work in narrative research unfolded?

People sometimes assume that I grew up in a storytelling family_and that's not at all the story that I tell. I grew up in a family that was part of a community and one of the things that was really important was people's experience. The familial curriculum making of my family was very nested in a larger extended family and also in a community where I learned about responsibility. Now that I think about it, I think of civic engagement, of living in community-minded and responsive ways. Then it was just that: we were responsible for ourselves, but also for the people, land, animals, neighbors and, of course, our family members.

It was experience that captured me, more than story. When I arrived to do my doctoral work, of course, I had already been teaching. I also worked as a school counsellor alongside elementary school teachers. When I arrived to do my doctoral work at OISE (Ontario Institute for Studies in Education), it was not with Michael Connelly, but with Frank Smith and John Mclnnes-it was my interest in language and trying to help children with reading and language skills because that was an area of great concern in the schools and that's the first thing that children were identified as having problems with that brought me to doctoral studies.

I had worked for about 10 years as a teacher, counsellor, and special programs teacher before I started my doctorate. That's important because when I arrived to do my doctoral work, one of the first courses I took was with Michael Connelly — and he had just started his work with Freema Elbaz. My great interest in their work was they were talking about something called "teacher knowledge." And everything I was reading in the literature basically was saying teachers didn't have knowledge. A new area of teacher thinking had just emerged and that just struck me as astounding because, of course, I knew teachers had knowledge. Teachers had rich experience: they always told stories of their teaching, but they were their stories of experience. And, of course, as a special programs teacher and 
school counsellor, I listened to many teachers tell their stories. I'd worked in their classrooms, I watched them live their stories in practice, and their knowledge was always experiential. When I ended up in this course with Michael, and reading Freema and his early work, I abandoned my interest in language arts and came over to really trying to work with their work around teacher knowledge. And trying to understand what teachers knew and what was expressed in their stories, both their lived and told stories.

But it took us a while to get to narrative. I have told this story in books and articles, and many times to people. It was actually Mark Johnson, the co-author with George Lakoff of, "Metaphors We Live By." It was Mark's influence when he said: "I think you should read Alasdair Maclntyre's book, "After Virtue." He said, "Don't read the whole thing-you'll be bored. In the moment I thought: What does that say about me?! He said, "Read the part about narrative unity." Mark's suggestion was the first time we explicitly talked about narrative and trying to understand stories and to see that the experiential knowledge teachers held was storied knowledge and that they expressed it in the stories they told and the stories that they lived by in their classrooms. And it helped me to see: "This is a much richer notion of what goes on in classrooms-it's a richer notion of teacher knowledge." It's kind of a backdoor way into narrative. It's always interesting to me over these many years: Had I stayed in language, would I have gotten to stories through a more "narratology" kind of way of thinking about teacher knowledge? But I didn't. I came to it through teachers' experience and understanding experiential knowledge.

Who are the scholars who have contributed to your work, and how have they done that?

As I said, Mark Johnson's "Metaphors We Live By," which I had already read before I met him. But then his work on embodied knowledge has always been really powerful. John Dewey's work is just essential_-"Experience in Education," "Art as Experience"- those books I devoured and are really central. But there were other people too: Carolyn Heilbrun's "Writing a Woman's Life" was really powerful; Mary Catherine Bateson's "Composing a Life" and then Maxine Greene's work toward the end of my doctoral work. She was my external examiner in my doctoral work. I loved Carol Gilligan's work, "In a Different Voice." The feminist scholars like Sandra Harding; this was a long time ago-but that was really radical stuff. I've been asked if my kind of turn to the feminist was because I'm a woman, and the answer to that is "maybe." But certainly, I think I've always been a feminist; they gave words to some of what I knew. But I think, as well, part of it is that so many elementary school teachers are women. The parents I interacted with most when I was teaching were mothers.

It was really interesting to come to the more feminist work-but also the feminist work that was very narrative; that was about voice, that was about experience. Those were the early years as we were doing that work. Nel Nodding's work on ethics and care, and on feminist ethics. When that book came out, "Caring," I was all over it—I think I'm on my third copy of it as I keep giving my copies away. Her work allowed me to think about the kind of research that we do; it allowed me to think about "voice" and about the relational work. I had already been thinking about that with Martin Buber's work, "I and Thou," which is another book that's so well marked up because he gave me much to think about. 
More recently, though it was still long ago, David Carr's work was very important. I, of course, read Foucault and Ricoeur-they didn't capture me in the same way that some of the other writers did. I knew what they were saying, but they seemed less grounded in people's experience, in the body. In that kind of sense of the social, as well as the personal, and that it's always a body in the world-it's a gendered body. And that I think comes from the experiential work. It's always someone in the world.

And I think someone told me to read Heidegger's work when I was a doctoral student. Instead, I read Hannah Arendt. I'm being reminded of her work again in some more recent work I'm doing with Vera Caine, but I read her books and was very taken with her ideas ... she called herself a "social political theory" writer. But what she was talking about ... about the experience of people ... about the private and the public ... was very important as I thought about teachers and teachers' experience ... and as I thought about understanding experience narratively.

In 1988, my colleague Miriam Ben-Peretz, who was then Dean of Education at Haifa; Madeleine Grumet; and Sally Brown, in Scotland, organized a little conference called "Private Women-Public Work." And that was a very narrative kind of conference at the University of Haifa. Hanna Arendt's work was really fundamental to that conference, but Madeleine Grumet was also important, certainly in thinking about her book, "Bitter Milk." Sandra Hollingsworth's work, in some ways, awakened me to narrative in a different way, thinking about teachers' lives over time.

What do you consider are the basic tenets of narrative inquiry in both classroom and research contexts?

Narrative inquiry is the study of experience. That's really fundamental. In order to understand experience, we have to understand experience over time: stories come from somewhere and go somewhere. We have to understand that it is a body in the world, so it's both personal and social always. It was interesting that we began trying to think about place a bit later in our work as we started to think about how important place was. It's important to understand that you can't kind of pull temporality, sociality, and place apart-they're always operating all the time. So, when we look at a child or teacher in a classroom, we have to see experience as something that's unfolding and enfolding over time, always in place or places, always social and personal. I get a little concerned when people only want to talk about the "personal" or they only want to talk about the "social." I say: "Well, you're not really thinking about narrative inquiry then, because if we're thinking narratively about experience, we have to be thinking in all of those ways at once." One of the really basic things is this kind of experiential focus.

Stories, when someone tells you the story-like I'm telling you stories now-you have to inquire into those stories. They're not little nuggets that you can take away and analyze. You always have to understand them as something composed; they're told in particular ways in particular times. Narrative inquiry involves inquiry into stories. Stories are always on their way, in the midst, in the making, because experience is always on the way. It comes from the intergenerational, from our early beginnings, the stories that were told in our early years. They get remade and retold, but they don't go away. They're always pointed in a direction. We have to understand that. Sometimes people want to smooth storied experience over and make it "first this and then this" as if there's some smoothness. 
There's no smoothness-it's always messy. And it's always also "intentional." The stories we live are always lived in, shaped by, intentions, within time, environment, context, larger narratives.

Those are fundamental things and I think they're fundamental as we think with teachers in classrooms that it is important to understand what teachers are doing. They are often not seen in this way, seen to be living their experiential knowledge in their classrooms. We offer a way of thinking about children as works in progress, children as composing their lives. Too rarely are teachers given the space to really think about who they are as teachers in relation with children in classrooms. I think, somehow, we need to slow things down for them, so they can have the moments to think about children. But, they write report cards all the time. I was just talking to one of my doctoral students who's in the midst of writing report cards. Report cards are, in some ways, the stories they are telling of a child's life making. Unfortunately, that's not the larger institutional narrative about report cards. They sometimes don't have time to really think, "I'm telling a life story of a child here ... I'm shaping this child's story." I think that's important for teachers, for all of us, to think about.

As researchers, these same things are always at work as we think about participants, as we think about the stories that participants tell us or allow us to come alongside as they live. It's really important to always know, whether we're a teacher in relation with a child and his or her family, that we're characters in that story and we need to be reflective and reflexive about who we are over time in those stories. And, as researchers, it's not a study of the "other"-it's always a study of us in relation with participants.

Can you share with us one of your favorite narrative inquiry stories and what you learned in the process?

I have many favorite narrative inquiry stories. I think I'Il share a story about a youth whose pseudonym is Jason, who's now a young man-he was part of a study we did with Indigenous youth. In this particular study, we set up an art club in a junior high school and we met every Wednesday with youth who chose to come. It was a large study with my colleagues Florence Glanfield, Vera Caine, Sean Lessard, Simmee Chung, Trudy Cardinal, Cindy Swanson ... there were a lot of us involved in that study. Jason came. He was in grade seven when he started to come to the art club. One of the first stories that Jason helped me see is that it is not the researchers alone who select participants, who select which youth we wanted to engage with more intensely and intently. We didn't understand that the youth, who knew it was research, and they knew that they might be selected to be with one or another of these many researchers. And Jason picked me, and it really woke me up to the ways that participants also come into the research with their own intentions and they knew who they wanted to work with.

Jason was not a youth who was really engaged with the art-making activities. He was really engaged in the food and he was engaged in the messing around. And he invited me, even though I was oblivious to this initially, by saying, "Will you hold my phone?" as he came into the art club. Now they, of course, all have phones-I don't really know the school policy, but he would ask me out of all the researchers who were there. One week, and then the next week, and then the next week, and finally I said to our little research group, "I think that Jason wants me to work with him." And it was like: "Of course, they're making up their own minds about who they want to work with and whether or not 
they wanted to be worked with." But I just hadn't seen that somehow. I was aware of this, but much more about the process of selecting research participants and thinking in some way, "I have the power to invite." He was letting me know that he actually had the power. When I asked, at first he was very hesitant. "Well," I said, "I have to talk to your mom." And he replied: "I don't remember her phone number." Well, there's no child who doesn't remember his mother's cellphone number. It took him quite a while before he said, "This is my mom's number; you can call her." Because he really wanted to continue this relationship. But it kind of shifted things and reminded me once again of the importance of thinking about who I was in that space and how I fitted into his story-not only how I was fitting him into my story. Because he's not the one I would of ... in all truth, I would have picked one of the girls who was sitting there nicely working on the various art projects or someone who was very focused on that. And this kind of a little bit unruly young man was picking me! That's one of my favorite stories because it calls me up short. Jason and I lived many other stories, but I think I'Il stay with that one for now. It reminded me of the importance of knowing that all the power doesn't rest with the researcher in narrative inquiry.

What challenges do researchers face in doing narrative inquiry?

Oh, the challenges are huge! They're less huge than they were, because I think we used to bump in very significant ways with research ethics boards that couldn't understand how there weren't a set number of interviews and where the power wasn't all with the researcher. Because so much of what the research ethics boards do kind of assumes that the power is with the researcher: we get to ask the questions/we get to select the participants/we get to say how long they'll meet. Some of that has lessened, but there's a still great sense of, "Well, what questions are you going to ask?" In response I say: "Well, this is where we'll start, but we have go where their experience and their stories and their life making takes us. So, we can't know. We aren't the only ones who get to decide how many conversations we'll have. That also depends on where the stories take us and it's a co-constructed relationship."

Some funding agencies still want us to be able to say what the findings are, i.e. we found these four things. Funding agencies, I think, are coming to a point now where sometimes I'm actually approached to take on research projects using narrative inquiry, because what they really want is to understand the experience of participants - they want to understand those experiences.

There are all of the issues of, "How do you find participants?" Sometimes, we work through institutions, through hospitals, through schools, through the university. When we don't have an institution to work through, then it's more difficult to find participants. When we were doing the narrative inquiry with teachers who had left teaching we faced that question of "How do we find participants?" There are those kind of issues. When we did the study with the youth who had left school early before graduating, it was also a challenge to find participants as we were used to finding them through schools, but they're not in schools. There are many issues around understanding that narrative inquiry really does ask you to do a lot of self-facing. The reflexive work is huge, to be able to say: "So, who am I in this? Why am I here? Why do I want to know about kids who leave school before graduating? And then how do I do that work on myself?" I think you need to be ready to do that. Sometimes people 
want research done so quickly ... the timeline is so short that you can't do the kind of work that narrative inquiry asks you to do. One of the big issues for people is the speed.

Of course, one of the huge issues is how we actually represent our research in a research text; how do we actually represent experiences of two people, a participant and a researcher who came together over time, told stories, lived alongside each other. How do we work with that to represent experience in text, which is still how we're asked to represent in dissertations ... and how do we represent this moving, living body in ethical research texts. Whether they're for journals, for final reports, for dissertations. So, that's another big issue.

I could go on about the issues forever, but I don't want to discourage people from doing this because it's so rewarding. You learn so much about yourself and it really asks you to live in the world in a different way. And if I can just go back to my growing up, I think my parents and my family were asking me to live in a world in a different way. They were asking me to be responsive and responsible for the kind of world that is being created and for who I am in that world. I think that narrative inquiry calls each of us to do that kind of work. And when I think about teachers in classrooms doing this kind of work, I think, if you think about children as composing their lives in classrooms, you're really called to think about them differently as more than a child who does or does not do the activities that you make in the classroom. It really calls you to think about: "So, who am I in this child's life and how can I come alongside this child, not to remake this child, but to come alongside in ways that he or she might able to tell his or her story and our stories differently.

Do you have any final comments you'd like to make?

I've been a researcher now for many years. I do think it's what's sustained me. It's what's called me to think about the world I'm part of in different ways. It calls me to be more wakeful to children and to teachers, and, of course, to nurses and young physicians who are just starting out, and to school principals. It calls me to think, to stay awake to the worlds that children and families and teachers and physicians live in. And to the larger narratives that we construct. I think so much about this right now, in part because of the work we're doing about Indigenous youth and their families, and those larger narratives in which their stories, their experiences, are nested. And how I need to think about who I am in their stories.

One of the current studies that we're just getting in the midst of is with refugee families. And trying to come alongside as they come to Canada, not because they wanted to leave their home country, but because their home country could no longer allow them to live there. I think about how it keeps me awake-I don't want to ever really stop being awake in the ways that narrative inquiry calls me to be awake. I do feel that it changes the world by asking us to be awake in different ways. We engage in policy and practice so much differently because of thinking narratively. 


\section{References}

Bateson, M. C. (1989). Composing a life. New York, NY: Grove Press.

Buber, M. (1970). I and thou (Kaufmann trans.). New York, NY: Charles Scribner's Sons. (Ger. 1921)

Dewey, J. (1934). Art as experience. New York, NY: Perigee.

Dewey, J. (1938). Experience in education. New York, NY: Collier.

Gilligan, C. (1982). In a different voice: Psychological theory and women's development. Cambridge, MA: Harvard University Press.

Grumet, M. (1988). Bitter milk: Women and teaching. The University of Massachusetts Press.

Heilbrun, C. (1988). Writing a woman's life. New York, NY: Ballantine Books.

Lakoff, G., \& Johnson, M. (1980). Metaphors we live by. University of Chicago Press.

MacIntyre, A. (1981). After virtue: A study in moral theory. University of Notre Dame Press.

Noddings, N. (1984). Caring: A feminine approach to ethics and moral education. Berkeley: University of California Press.

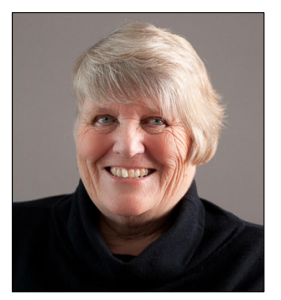

D. Jean Clandinin is Professor Emerita and Founding Director of the Centre for Research for Teacher Education and Development at the University of Alberta. A former teacher, counsellor, and psychologist, she is author or coauthor of 17 books and many articles and book chapters. Her last book with Michael Connelly, Narrative Inquiry, was published in 2000. She edited the Handbook of Narrative Inquiry: Mapping a Methodology (Sage, 2007) and the Handbook of Research on Teacher Education (Sage, 2017). She has just completed three books with Left Coast Press/Routledge: Engaging in Narrative Inquiry (2013), Engaging in Narrative Inquiry With Children and Youth (2016), and Relational Ethics in Narrative Inquiry (2018). 
D. Jean Clandinin

24 | LEARNing Landscapes | Spring 2018, Vol. 11 No. 2 